\title{
The Impact of Residential Customer Participation on Purchasing Intention: The Mediating Effect of Customer Perceived Value
}

\author{
Yabing Liu ${ }^{a}$, Hongliang $\mathrm{Yu}^{\mathrm{b},{ }^{*}}$ and Yihua Mao ${ }^{\mathrm{c}}$ \\ Zhejiang University, College of Civil Engineering and Architecture, Hangzhou, Zhejiang, China. \\ a liuyabing@zju.edu.cn, ${ }^{*}, \mathrm{~b}$ yhl@zju.edu.cn, c zjumyh@163.com
}

\begin{abstract}
This study explores the influence of customer participation on purchase intention in the process of commercial residential purchasing from the perspective of customer perceived value. The aim of the study is to construct a model in which the customer participation indirectly influences the purchase intention through the customer perceived value. First of all, the customer participation scale, the customer perceived value scale and the purchase intention scale of the commercial residential buildings were constructed and tested. Data from a sample of 133 buyers showed that customer participation positively influenced purchase intentions and customers perceived value (quality value, economic value, social value, and emotional value) played a mediating role in this positive relationship.
\end{abstract}

\section{Introduction}

There are both investment properties and living properties in commercial housing, and the living properties are fundamental. In order to better meet their own needs, buyers will invest a lot of time, energy and resources to know the residential products. The formation of their purchase intention is closely related to their participation. How does the customer participation influence the purchase intention in the field of commercial residential research? This article attempts to examine the positive role of customer participation in purchasing intentions and introduces customer perceived value to the commodity residential house.

The customer perceived value refers to the consumer's overall assessment of the products or services based on their trade-offs between what is received and what is given [1]. In this study, it is defined as buyers' subjective evaluation of a particular commodity residential based on the benefits they perceived in the product relative to the sacrifice they perceived by paying the price. Sheth, Newman, and Gross put forward five kinds of perceived values that affect customer's consumption behavior: functional value, social value, emotional value, epistemic value and conditional value [2]. Sweeney and Soutar further divided functional value into two dimensions: functional value quality factor and functional value price factor. They constructed the customer perceived value PERVAL model, including emotional value, emotional value, social value, and functional value - price / value for money and functional value - quality / performance [3]. Bai Shumin analyzed the relationship between customer participation, customer perceived value and purchase intention in the real estate purchase process, but she did not conduct empirical research [4]. Based on the above research results, this study conducts an empirical investigation of the relationship among the three variables of customer participation, customer perceived value and purchase intention in the commercial residential market to explore the mediating effect of customer perceived value.

\section{Models and Assumptions}

The independent variables considered in this study is customer participation and the dependent variables analyzed in this study is purchase intention. The mediating variable selected for in this is customer perceived value, including four dimensions of quality value, economic value, social value and emotional value (Fig. 1). 


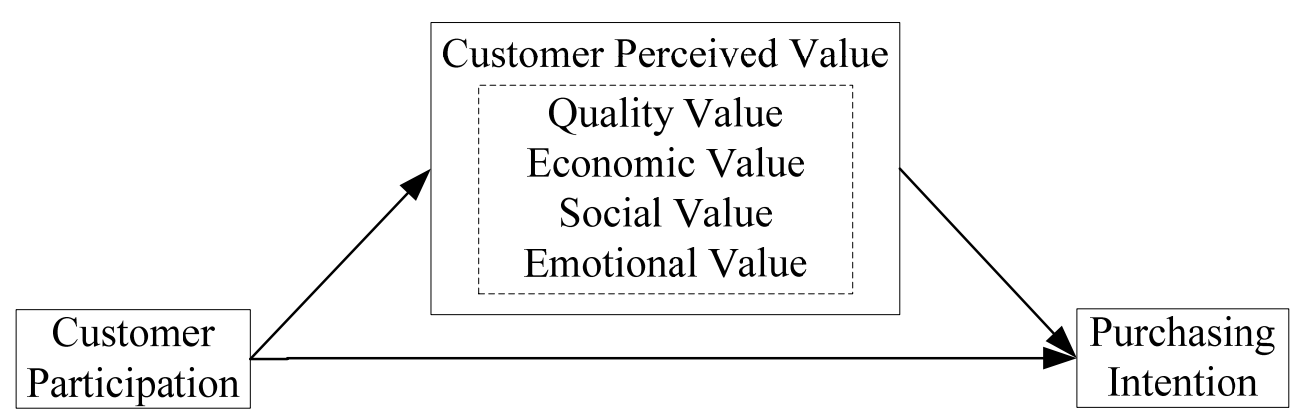

Figure 1. Research framework

\subsection{The Impact of Customer Participation on Purchasing Intention.}

Literature showed that the higher the degree of customer participation, the stronger their behavioral intentions. Wang Xinxin constructed a research model of repeat purchase intention of customers in $\mathrm{B} 2 \mathrm{C}$ online shopping market and found that customer participation in information exchange and interpersonal interaction had a significant positive impact on repeat purchase intention [5]. Huang Yaojia conducted an online shopping survey and empirically tested the impact of customer participation on the online consumer willingness to communicate through the indirect impact of relationship quality [6]. Thus, it is hypothesized that:

H1: Customer participation has a positive impact on purchase intention.

\subsection{The Impact of Customer Participation on Customer Perceived Value}

Wang Tao, Cui Nan and Yang kui used scenario simulation experiments to verify that customer participation has a positive impact on customer perceived value based on the mental accounting theory [7]. Dai Debao and Gu Xiaohui found that social network users' browsing behavior, interactive behavior, creating behavior had a significant positive impact on perceived value [8]. The impact of participatory behavior on perceived value has been confirmed by a large number of scholars, so we predict:

$\mathrm{H} 2$ : Customer participation has a positive impact on customer perceived value.

H2a: Customer participation has a positive impact on customer perceived quality value.

$\mathrm{H} 2 \mathrm{~b}$ : Customer participation has a positive impact on customer perceived economic value.

$\mathrm{H} 2 \mathrm{c}$ : Customer participation has a positive impact on customer perceived social value.

H2d: Customer participation has a positive impact on customer perceived emotional value.

\subsection{The Impact of Customer Perceived Value on Purchasing Intention}

Literature showed that perceived value is an important antecedent variable of behavioral intention. He Jianmin and Pan Yongtao empirically demonstrated that customer perceived value has a direct and positive impact on behavioral intentions [9]. Chang \& Wildt investigated 425 university business students and found that perceptual value and perceived quality balance to form perceived value, and perceived value is the main factor affecting the purchase intention [10]. Huang Wenyan and Laochen Feng elucidated that customer perceived value had a partial mediating effect on the influence of online word-of-mouth and purchase intention [11]. Guo Tonghua and Tang Chunhui investigated the consumer behavior of e-coupons and verified the mediating effect of customer perceived value in customer participation and purchase intention through regression model [12]. According to these researches, it is expected that:

H3: Customer perceived value has a positive impact on purchase intention.

$\mathrm{H} 3 \mathrm{a}$ : Customer perceived quality value has a positive impact on purchase intention.

$\mathrm{H} 3 \mathrm{~b}$ : Customer perceived economic value has a positive impact on purchase intention.

H3c: Customer perceived social value has a positive impact on purchase intention.

H3d: Customer perceived emotional value has a positive impact on purchase intention.

H4: Customer perceived value mediates the relationship between the customer participation and purchase intention.

H4a: Customer perceived quality value mediates the relationship between the customer participation and purchase intention. 
H4b: Customer perceived economic value mediates the relationship between the customer participation and purchase intention.

H4c: Customer perceived social value mediates the relationship between the customer participation and purchase intention.

H4d: Customer perceived emotional value mediates the relationship between the customer participation and purchase intention.

\section{Method}

The study adopted a questionnaire survey. All items used measurement by Likert scale of 1 to 7 representing an increasing degree of agreement. The measurement of customer participation includes 8 items for commercial residential buildings, referring to the multi-dimensional scale for Chinese consumers developed by Peng Yanjun [13]. The customer perceived value measurement using the four-dimensional model of Sweeney and Soutar [3], namely quality value, price value, social value and emotional value, contains a total of 13 items. Purchase intention is measured by three aspects: consider the purchase, recommended purchase and premium purchase.

We used convenient sampling methods in non-probabilistic sampling and selected the participants who were interested in the purchase of commercial housing with a certain economic base, and had concerned about a particular real estate. A total of 150 questionnaires were distributed, and 133 questionnaires were found valid $(88.7 \%)$.

\section{Results}

\subsection{Reliability Analyses}

Cronbach's $\alpha$ coefficient was used to test the reliability of the scales. It is generally considered that Cronbach's $\alpha$ is between 0.7 and 1 with high reliability. The results showed that the Cronbach's $\alpha$ of customer participation, customer perceived value and purchase intention were $0.831,0.926$ and 0.764 respectively. For the customer perceived value, Cronbach's $\alpha$ of quality value, economic value, social value and emotional value were $0.851,0.830,0.909$, and 0.889 respectively. Therefore, the scale used in this study had high reliability and the questionnaire items have good internal consistency.

\subsection{Validity Analyses}

Exploratory factor analysis was used to evaluate the structural validity of the customer perceived value scale. The Kaiser - Meyer - Olkin (KMO) measure of sampling adequacy $(=0.886)$ and Bartlett's test of sphericity $(\mathrm{p}<0.001)$ confirmed that the sample was suitable for principal component analysis. Principal component analysis showed that there were four main factors (Table 1). Each items were attributed to factors with loading at least 0.7 , indicating that the items have a high explanatory power of the corresponding factors. At the same time, no significant cross-factor loading occurred with the factor loading is less than 0.4 in the irrelevant factor. Attribution of the items to their factors showed that the first factor covers social value, the second factor covers quality value, the third factor covers economic value, and the fourth factor covers emotional value.

Table 1. The results of exploratory factor analysis of customer perceived value

\begin{tabular}{|c|c|c|c|c|c|}
\hline \multirow{2}{*}{ Variable } & \multirow{2}{*}{ Items } & \multicolumn{4}{|c|}{ Component } \\
\hline & & Factor 1 & Factor 2 & Factor 3 & Factor 4 \\
\hline \multirow[t]{3}{*}{ Quality Value } & PV1 & 0.085 & 0.747 & 0.187 & 0.364 \\
\hline & PV2 & 0.203 & 0.863 & 0.174 & 0.212 \\
\hline & PV3 & 0.169 & 0.809 & 0.239 & 0.117 \\
\hline \multirow[t]{3}{*}{ Economic Value } & PV4 & 0.148 & 0.199 & 0.824 & 0.171 \\
\hline & PV5 & 0.235 & 0.143 & 0.767 & 0.201 \\
\hline & PV6 & 0.272 & 0.289 & 0.761 & 0.203 \\
\hline \multirow[t]{4}{*}{ Social Value } & PV7 & 0.828 & 0.212 & 0.254 & 0.234 \\
\hline & PV8 & 0.874 & 0.121 & 0.191 & 0.181 \\
\hline & PV9 & 0.901 & 0.182 & 0.154 & 0.147 \\
\hline & PV10 & 0.778 & 0.078 & 0.188 & 0.284 \\
\hline \multirow[t]{3}{*}{ Emotional Value } & PV11 & 0.331 & 0.172 & 0.362 & 0.727 \\
\hline & PV12 & 0.297 & 0.340 & 0.208 & 0.770 \\
\hline & PV13 & 0.229 & 0.257 & 0.165 & 0.838 \\
\hline
\end{tabular}




\subsection{Mediating Effect of Customer Perceived Value}

We used regression analysis to test the intermediary role of customer perceived value between customer participation and purchase intention. The analysis results are shown in Table 2. Model $1 \sim 3$ takes customer participation as independent variable, purchase intention as dependent variable, and customer perceived value as mediating variable, and carries out three-step regression analysis. In the first step, Model 1 shows that customer participation has a significant positive impact on purchase intention $(\beta=0.492, t=5.268, p<0.001)$, so hypothesis $\mathrm{H} 1$ is accepted. In the second step, Model 2 shows that customer participation has a significant positive effect on quality value $(\beta=0.679, \mathrm{t}=$ 7.888, $\mathrm{p}<0.001$ ), so hypothesis $\mathrm{H} 2 \mathrm{a}$ is accepted. In the third step, Model 3 tests the effect of customer participation and quality value on purchase intention at the same time and finds that customer participation has no significant effect on purchase intention $(\beta=0.186, t=1.791, p>0.1)$, while quality value has a significant positive impact on purchase intention $(\beta=0.451, \mathrm{t}=5.218, \mathrm{p}<$ $0.001)$. It means customer perceived quality value plays a complete intermediary role in the impact of customer participation on purchase intention, so hypothesis $\mathrm{H} 3 \mathrm{a}$ and $\mathrm{H} 4 \mathrm{a}$ are accepted. In the same way, model 4 and model 5, model 6 and model 7, model 8 and model 9 respectively test the intermediary role of economic value, social value and emotional value. The results show that economic value, social value and emotional values all play a part intermediary role in the impact of customer participation on the purchase intention, and all of the hypotheses above are accepted.

Table 2. The results of mediate effect

\begin{tabular}{|c|c|c|c|c|c|c|c|c|c|}
\hline & Model 1 & Model 2 & Model 3 & Model 4 & Model 5 & Model 6 & Model 7 & Model 8 & Model 9 \\
\hline Variable & $\begin{array}{l}\text { Purchase } \\
\text { Intention }\end{array}$ & $\begin{array}{l}\text { Quality } \\
\text { Value }\end{array}$ & $\begin{array}{l}\text { Purchase } \\
\text { Intention }\end{array}$ & $\begin{array}{l}\text { Economic } \\
\text { Value }\end{array}$ & $\begin{array}{l}\text { Purchase } \\
\text { Intention }\end{array}$ & $\begin{array}{l}\text { Social } \\
\text { Value }\end{array}$ & & $\begin{array}{l}\text { Emotional } \\
\text { Value }\end{array}$ & \\
\hline (Constant) & $\begin{array}{l}1.95 * * * \\
(4.168)\end{array}$ & $\begin{array}{c}1.572 * * * \\
(3.646)\end{array}$ & $\begin{array}{l}1.240^{* *} \\
(2.767)\end{array}$ & $\begin{array}{c}2.955^{* * *} \\
(6.849)\end{array}$ & $\begin{array}{c}0.713 \\
(1.413)\end{array}$ & $\begin{array}{c}2.253 * * * \\
(4.537)\end{array}$ & & $\begin{array}{c}2.127 * * * \\
(4.504)\end{array}$ & \\
\hline $\begin{array}{l}\text { Customer } \\
\text { Participation }\end{array}$ & $\begin{array}{c}0.492 * * * \\
(5.268)\end{array}$ & $\begin{array}{c}0.679 * * * \\
(7.888)\end{array}$ & $\begin{array}{c}0.186 \\
(1.791)\end{array}$ & $\begin{array}{c}0.439 * * * \\
(5.090)\end{array}$ & $\begin{array}{c}0.309 * * * \\
(3.260)\end{array}$ & $\begin{array}{c}0.336^{* * *} \\
(3.384)\end{array}$ & $\begin{array}{c}0.344 * * * \\
(3.981)\end{array}$ & $\begin{array}{c}0.531^{* * *} \\
(5.634)\end{array}$ & $\begin{array}{l}0.254 * * \\
(2.721)\end{array}$ \\
\hline $\begin{array}{l}\text { Quality } \\
\text { Value }\end{array}$ & & & $\begin{array}{c}0.451 * * * \\
(5.218)\end{array}$ & & & & & & \\
\hline $\begin{array}{l}\text { Economic } \\
\text { Value }\end{array}$ & & & & & $\begin{array}{c}0.418^{* * *} \\
(4.770)\end{array}$ & & & & \\
\hline $\begin{array}{l}\text { Social } \\
\text { Value }\end{array}$ & & & & & & & $\begin{array}{c}0.442 * * * \\
(6.058)\end{array}$ & & \\
\hline $\begin{array}{l}\text { Emotional } \\
\text { Value }\end{array}$ & & & & & & & & & $\begin{array}{c}0.449 * * * \\
(5.800)\end{array}$ \\
\hline$R^{2}$ & 0.175 & 0.322 & 0.318 & 0.165 & 0.298 & 0.080 & 0.356 & 0.195 & 0.344 \\
\hline$F$ & $27.751 * * *$ & $62.218^{* * *}$ & $30.265^{* * *}$ & $25.907 * * *$ & $27.556^{* * *}$ & $11.453 * * *$ & $36.005 * * *$ & $31.737 * * *$ & $34.153 * * *$ \\
\hline
\end{tabular}

Note: $(1) * p<0.05,{ }^{* *} p<0.01,{ }^{* * *} p<0.001 ;$; $(2) t$ in brackets.

\section{Conclusion}

Through empirical research, we find that customer participation has a significant positive effect on purchase intention in the process of commercial residential purchase, and customer perceived value plays an intermediary role in this relationship. The quality value of customer perceived value plays a complete intermediary role, and the economy value, social value and emotional value play a part of the intermediary role.

\section{References}

[1]. V.A. Zeithaml, Journal of Marketing, Vol. 52 (1988) No.3, pp.2-22.

[2]. J.N. Sheth, B.I. Newman and B.L. Gross, Journal of Business Research, Vol. 22 (1991) No.2, pp. 159-170.

[3]. J.C. Sweeney and G.N. Soutar, Journal of Retailing, Vol. 77 (2001) No.2, pp.203-220. 
[4]. S.M. Bai, Rural Economy and Science-Technology, Vol. 27 (2016) No.14, pp.213-243. (In Chinese)

[5]. X.X. Wang, The Influence of Customer Participation, Relationship Quality on Customer Repurchase Intention in B2C Online Market (MS., Dongbei University of Finance and Economics, China, 2012). (In Chinese)

[6]. Y.J. Huang, The Influence of Customer Participation on Internet Word-of-mouth Pass along Intention (MS., South China University of Technology, China, 2012). (In Chinese)

[7]. T. Wang, N. Cui and K. Yang, Journal of Business Economics, Vol. 217 (2009) No.11, pp.81-88. (In Chinese)

[8]. D.B. Dai and X.H. Gu, Consumer Economics, Vol. 33 (2017) No.2, pp.58-65. (In Chinese)

[9]. J.M. He and Y.T. Pan, Modernization of Management, Vol. 35 (2015) No.1, pp.28-30. (In Chinese)

[10]. T.Z. Chang and A.R. Wildt, Journal of the Academy of Marketing Science, Vol. 22 (1994) No.1, pp.16-27. (In Chinese)

[11]. W.Y. Huang and C.F. Lao, Consumer Economics, Vol. 29 (2013) No.5, pp.48-53. (In Chinese)

[12]. T.H. Guo and C.H. Tang, Techno economics \& Management Research, (2011) No.9, pp.49-53. (In Chinese)

[13]. Y.J. Peng, Management Review, Vol. 22 (2010) No.3, pp.78-85. (In Chinese) 